\title{
Rewiring higher education for the Sustainable Development Goals: the case of the Intercultural University of Veracruz, Mexico
}

\author{
Cristina Perales Franco ${ }^{1} \cdot$ Tristan McCowan $^{2}$
}

Published online: 14 March 2020

(C) The Author(s) 2020

\begin{abstract}
In the framework of the Sustainable Development Goals, higher education has been given a key role in addressing societal challenges, reducing poverty, ensuring sustainable livelihoods and protecting the natural environment. Yet there has been a singular lack of imagination as regards the institutional forms that might help support this vision. This article reports on the findings of an exploratory qualitative case study of the Intercultural University of Veracruz, one of a number of institutions created in Mexico to ensure access for indigenous populations, to promote local development and to provide a space for intercultural dialogue. The findings show a number of ways in which this innovative institution provides opportunities for supporting the SDGs that go beyond conventional universities. The university addresses SDG4 by enabling access for marginalised populations, and through its engaged teaching, research and community engagement also contributes to environmental protection, health, livelihoods, gender equality and a range of other goals. However, it also presents challenges to the global framework, highlighting the lack of attention to culture, language, identity and knowledge traditions, and in critiquing the very basis of its conception of development. Implications are drawn out more broadly for the relationship between higher education and international development in the contemporary era.
\end{abstract}

Keywords Community engagement · Indigenous education · Intercultural universities · Mexico · SDGs

Cristina Perales Franco

cristinaperalesf@gmail.com

Tristan McCowan

t.mccowan@ucl.ac.uk

1 Instituto de Investigaciones para el Desarrollo de la Educación, Universidad Iberoamericana, Prolongación Paseo de la Reforma 880, Lomas de Santa Fe, 01219 Ciudad de México, Mexico

2 Institute of Education, University College London, 20 Bedford Way, London WC1H0AL, UK 


\section{Introduction}

The new-found faith in higher education evident in the Sustainable Development Goals (SDG) framework - in which the university appears not only as a goal in its own right but also as a means of attaining the full set of 17 goals - is based primarily on its role in developing human capital and generating scientific breakthroughs, allowing for the emergence of new technologies. These two roles are doubtless important in achieving the human well-being and environmental protection dimensions of the global development frameworks. Yet they leave some important questions unanswered. Which forms of professional development should be prioritised by the university, and how can we ensure that graduates will be contributing to the public good rather than maximising their private returns and exacerbating social reproduction? How can we direct the knowledge produced by the university towards addressing the most urgent societal needs and ensure that it will be taken up meaningfully by the appropriate communities?

These questions alert us to the fact that simply rolling out more higher education will not necessarily address these issues. Universities have tremendous potential as a driver for inclusive development, yet whether they can fulfil their potential depends on their values, their internal configurations and their posture towards society (McCowan 2016a, 2019). In short, it is not any university that will do in achieving the SDGs. In international efforts surrounding the framework, much more attention is needed to institutional forms, to experimentation with new models and particularly to local innovations that might be effective within particular geographical and cultural contexts.

The intercultural universities (IUs) in Mexico represent a promising innovation in this regard. From 2003, a system of 11 of these institutions has been created in different states in Mexico, along with five others generated by private institutions, community initiatives or NGOs (Mateos Cortés and Dietz 2016; Rojas Cortés 2016). These universities are not exclusively for the indigenous population (Schmelkes 2009), but in contrast to the urbancentric and classist university tradition in the country, are located in indigenous regions, in cultural settings characterised by high economic exclusion and infrastructural marginalisation (Mateos Cortés and Dietz 2016; Salmerón Castro 2013). The main purposes of these universities are thereby to increase the proportion of indigenous students in higher education, to educate professionals engaged with regional development and to form links with the communities in which they are located (Schmelkes 2008).

This article explores the case of one of these universities, the Intercultural University of Veracruz (Universidad Veracruzana Intercultural - UVI), which has been particularly successful in providing differentiated provision for rural indigenous communities. The aim of the article is first to assess the potential for local innovation in higher education to address the SDGs, principally through new modes of community engagement and professional development. As an exploratory study, it aims to generate ideas to underpin a fuller research agenda, as well as engaging with theoretical dimensions of the question. Moreover, there is a problematising role to the research. One of the significant aspects of the case is that it serves not only as an effective conduit for achieving the SDGs but also to critique them. As will be explored further below, UVI highlights some of the blind spots of the framework, particularly in relation to epistemic and cultural dimensions, and allows us to broaden our imagination of possible responses.

The article presents findings from a qualitative case study conducted in 2017 , involving fieldwork in UVI's headquarters and in one of its satellite campuses, involving both of the 
authors. The purpose of the article is not to provide an emic perspective on the experience of the university (there are a number of accounts of this type already e.g. Gómez Navarro 2014; Meseguer Galván 2013; Mateos Cortés et al. 2016), but to engage it in dialogue with the external frame of the SDG framework, in order to understand, interrogate and problematise the relation between the local and global. The article will start by providing background information on the higher education system in Mexico and the intercultural universities, before presenting the methodology of the study, the main findings, an analysis of their relevance for the SDGs and the challenges they pose. Finally, the implications for a broader understanding of the role of higher education in the SDGs are drawn out.

\section{Mexican higher education and the establishment of the intercultural universities}

Higher education policy in Mexico in recent decades has focused primarily on expanding provision (Mendoza-Rojas 2015). ${ }^{1}$ According to the National Association of Universities and Higher Education Institutions (ANUIES ${ }^{2}$ ), there was a 20.6\% gross enrolment ratio in the year 2000. In contrast, in the year 2017-2018, the percentage was of $38.4 \%$, which accounts for $4,562,182$ students enrolled in over 3000 institutions (ANUIES 2018; INEE 2019). Of these students, $92 \%$ attend undergraduate programmes, and $8 \%$ are at the graduate level. The number of teaching staff has also grown; in the same period, there were around 217,000, $85 \%$ more than in the year 2000 (ANUIES 2018).

Higher education is mainly public at the undergraduate level. After the significant increase in privately enrolled students in the 1990s, from the year 2003, the proportion has stabilised with little change: 3 out of 10 students attend privately funded institutions at the undergraduate level (ANUIES 2018; Mendoza-Rojas 2015), while at the post-graduate level, the proportion rises to 6 out of 10 (ANUIES 2018).

The higher education system has also diversified, with ANUIES distinguishing between 11 public subsystems. The three larger ones in terms of their number of students are the state public universities (26\% of the enrolment), federal public universities $(10.5 \%)$ and the federal technological institutes $(7.6 \%)$. The smallest are the CONACYT research centres, which mainly have post degree programmes $(0.1 \%)$, and the intercultural universities $(0.3 \%)$. The IU had in the year 2017-2018 a total of 13,784 students (ANUIES 2018).

Higher education in Mexico is characterised by three trends. The first is political decentralisation, since it is mainly local actors in the different states that decide the type of higher education they will offer and the location of the institutions. The second is administrative decentralisation, given that the variety of autonomous subsystems at the state level has strengthened and increased. Finally, there has also been territorial deconcentration, fostering the instalment of new institutions in rural areas and mid-size cities, as well as in municipalities that did not previously have higher education provision (Mendoza-Rojas 2015).

Although there has been an important improvement in terms of educational coverage across the country, Mexico is still behind other countries in the Latin American region, like Colombia

\footnotetext{
${ }^{1}$ In the most recent educational reform of 2019 (DOF 2019), higher education has been positioned in the Constitution as obligatory, and the federal and local authorities are responsible now for providing the educational service to all the population that meet the requirements and have the desire to attend (INEE 2019).

${ }^{2}$ Asociación Nacional de Universidades e Instituciones de Educación Superior.
} 
(gross enrolment ratio of 58.7\%), Argentina (85.7\%) and Chile (90.3\%) (UNESCO, 2018 in ANUIES 2018, p. 28). There are also important issues regarding equity in higher education. There are gaps between the different states regarding coverage, with the southern states, including Veracruz where this study takes place, having less provision (ANUIES 2018; Mendoza-Rojas 2015). There is also an uneven distribution of access in terms of the social background of the students: $54 \%$ of the higher education students belong to the four higher earning deciles and only 24\% to the four lower ones (INEGI 2016, see also Silva Laya 2019). The challenges of accessing and finishing higher education are also increased for rural and indigenous students (INEE 2019).

There are also recognised issues related to the plurality and fragmentation of the higher education system, such as the lack of articulation and of consistent policy, as well as insufficient and unstable funding (Mendoza-Rojas 2018; ANUIES 2018). The low quality of some of the higher education institutions in terms of academic achievement, low employment rates for graduates and the high number of part-time staff, with unstable working conditions and little training regarding teaching methods, have also been highlighted (OECD 2019; ANUIES 2018).

It is against this backdrop of significant inequalities that the intercultural universities were established. The project was made possible by the convergence of the goals of social policy (aimed at fighting poverty), higher education policy oriented towards the previously described increase in coverage, the formation of human capital and the intercultural agenda, promoted by the national and international indigenous movement (Tapia Guerrero 2016). The IUs are positioned as a response to three particular demands of the indigenous groups in Mexico: access to bilingual and culturally pertinent education; better national knowledge and appreciation of indigenous culture and to decide about their own educational systems - with the necessary resources to plan, execute and evaluate them, as Schmelkes (2009) points out. For this author, however, the IUs "are clearly an answer to the first of these demands. In time, they should become a main instrument for the gradual fulfilment of the other two" (2009 p. 8-9). Other analyses challenge the possibility of fully addressing them, since IUs have been subordinated to the national public policy and to a particular model of understanding intercultural relations (e.g. Tapia Guerrero 2016), positioning this system more as a case of affirmative action (Lehmann 2015).

Research on the development of the IUs in Mexico has emerged in the last 10 years, but is unequally distributed across topics and the different universities. It has dealt mostly with analysis of the normative frame, institutional educational offer, public policy and the implementation process (Alcántara Santuario and Navarrete Cazales 2014; Bertely Busquets 2011; Didou-Aupetit 2013; Dietz 2009; Fábregas Puig 2009; González Ortíz 2007; Sandoval Forero and Guerra García 2007; Schmelkes 2009), conceptions and practices of interculturality (Ávila Romero and Ávila Romero 2014; Dietz and Mateos Cortés 2010; Lebrato 2016; Lehmann 2015; Llanes Ortíz 2009; Sartorello 2009) and with experiences and trajectories of students (Ávila Romero and Ávila Romero 2014; Bermúdez Urbina and González Apodaca 2016; Esteban et al. 2009; Oviedo Mendiola 2014; Sartorello 2016). In terms of analysing their impact, the research literature has been less developed, with only some available evidence regarding IU graduates. Rojas Cortés (2016) states, for example, that graduates perceive a strengthening of their ethnic identities and return to the local communities - where they are usually the first ones in their families to go to university. They are also perceived in the literature as acting as intermediaries in their origin or host communities, often working in the government (Villa 2015) or NGOs (Rojas Cortés 2016). Two other texts were found where 
impacts of the IUs are presented, in one the role of the research projects in local communities aimed at recovering and valuing local knowledge (Morales Silva 2012) and the participation of the IU lecturers and students in advising local NGOs (García and Bastida Muñoz 2012). These texts are mainly descriptive of the process, without necessarily presenting an assessment of the impact of the IU in the local contexts.

UVI, the focus of this article, is one of the IUs in which most academic production has been developed. Its implementation and processes have been systematised and analysed mainly by researchers associated with the Universidad Veracruzana and the UVI itself (e.g. Dietz 2008; Mateos Cortés and Dietz 2014) and by some external researchers (e.g. Re 2013; Lehmann 2015). The literature analysing the processes of this institution covers some of the same areas presented in the case of the whole UI system (e.g. Re 2013, on identity; Dietz 2012, on meanings of interculturality; and Guzmán Gamés 2014 and Meseguer Galván 2013, on students' trajectories) but a particular emphasis can be seen in analysing the intercultural curricular model (e.g. Ávila Pardo and Cortés Mateos 2008; Mendoza Zuany 2009; Olivera Rodríguez 2017) and the processes of mediation between the actors (e.g. Mateos Cortés 2008; Dietz and Mateos Cortés 2010). Although no specific research has been found on the impact of the universities in their local contexts, there are some contributions regarding the relationship with one of the host communities (Araujo Echevarría 2013) and the trajectories and experiences of the UVI graduates (Gómez Navarro 2013, 2014; Mateos Cortés et al. 2016; Mateos Cortés 2015; Moreno Arriba 2016).

\section{Research methods}

The study was conducted in 2017 and consisted of an exploratory case study (Merriam 1998), aiming to research a pilot case. The focus was on the way the SDGs could be understood, implemented and challenged in higher education settings that did not constitute traditional university institutions, and that presented innovative ways of developing higher education. The UVI and its satellite campus were therefore chosen following a purposeful sampling strategy (Patton 1990), since they constituted information-rich scenarios where there were enough background information and previous literature that allowed the researchers to start exploring the research aims. The satellite campus was also chosen for its accessibility and safety, important concerns in the state of Veracruz.

In terms of data collection, a total of 23 semi-structured interviews were conducted with students, lecturers, senior management, researchers, alumni and community members. The interviews carried out with researchers and senior management were of the key informant type, selected on the basis of their crucial or unique roles in relation to the institution. The selection of students, lecturers, alumni and community members was partly pragmatic, not only on the basis of availability during the period of field research but also the degree of involvement with the institution. These interviews addressed the characteristics of the UVI model, the informant experiences and perspectives and if and how they perceived a relationship between the UVI practices and the SDGs. The study also draws on evidence from observations carried out on campus on specific events, such as a graduation examination and an assembly, documentary sources provided by the institution and previous literature. The data were thematically analysed using Atlas.ti focusing on the UVI model, informant perceptions, explicit and implicit links to the SDGs and challenges to the SDGs framework. 
The main lens for analysing this case is the interaction between local and global frameworks of development - along the lines of Vavrus and Bartlett's (2006) vertical case study, and with a conscious emphasis on the etic. In this particular case, the focus is on the global framework of the SDGs and the extent to which an intercultural university supports, dialogues with or challenges that framework. The discussions also draw on theoretical ideas of postdevelopment (e.g. Escobar 1995; Rahnema and Bawtree 1997; Prakash and Esteva 2008), which interrogate the embedded logics of development - economic growth, modernisation, liberal institutions etc.- - from the perspective of excluded populations, challenging the deficit discourse and acknowledging multiple and equally valid forms of community and society.

\section{The Intercultural University of Veracruz}

The Universidad Intercultural Veracruzana (UVI) was created in 2005 under the umbrella of the much larger public university of the state of Veracruz (Universidad Veracruzana, with approximately 80,000 students). This status gives it more stability in comparison with the other 10 IUs that were created directly by the federal and state educational authorities. The Universidad Veracruzana is an autonomous university, meaning it is capable of making its own academic and financial decisions. While UVI is to some extent subject to the overall regulations of its parent institution, it has a significant degree of autonomy within it, and as explained further below, has carved out its own pedagogical model and admissions criteria that are distinct. Furthermore, it is buffeted from local politics: in contrast, the other IUs depend on their local congresses and government in terms of budget and appointment of leadership.

The UVI project emerges from several political, educational and epistemological positions that reflect some of the current tensions found in the field, some of which will be explored below in relation to the SDGs. According to one of the researchers interviewed for this project, three main drivers can be highlighted. A first one aimed at offering intercultural higher education for young people in their own regions and appropriate for their needs and characteristics which would give them the chance to stay in their own communities or keep on studying. A second one, derived more from NGOs, aimed at ensuring the provision of local professionals who could substitute outsiders and could foster the development of more locally rooted projects. Finally, a third that saw the UVI project as a possibility for the development of a more radical agenda aimed at the recognition and autonomy of the indigenous population. For this researcher, in the history of the UVI, there has always been a complicated relationship between access and what the actors believe to be an appropriate education:

Of course, one thing is coverage and another is pertinence. The quality criteria always had that contradiction and they keep on having it. When the UVI dean goes to Mexico City, and the Undersecretary of Higher Education asks her "how many students do you have?"..."Any online system is cheaper than the four people in the Zongolica mountains", meaning, that it does not have an impact. But on the other hand we see a strong local and regional impact, because now there are professionals that are former UVI students in all the local councils, and in practically all the NGOs [...] And there are governmental institutions that used to outsource professionals $[. .$.$] now in the campaign$ against hunger, the national population census, the preparation of elections, all of it at a local level would not be possible without the UVI alumni [...] (researcher1, male) 
The UVI is a university formed by four regional campuses in the state of Veracruz. Veracruz is situated in the eastern part of Mexico, covering most of the shoreline of the Mexican Gulf. It is the state that has the third largest population in Mexico, over 8 million people (CONAPO 2018), and the third as well in indigenous population, 1,101,306 people (CDI 2015a). The most important indigenous groups in the state are Nahuas, Totonacos, Huastecos, Popolucas and Zapotecos (CDI 2015b). Educationally, Veracruz's population of 15 years old or more presents lower indicators than the national averages. The state average of school years of enrolment is $8.2 \mathrm{vs}$ the national average of 9.2 and the illiteracy rate is $10.4 \%$, significantly higher to the national rate of $6 \%$ (INEE 2019). The state coverage of higher education is of $32.6 \%$ gross enrolment ratio, which is lower than the national mean of $38.4 \%$ presented above. Such indicators are strongly associated with the high marginalisation of the state's population: $62.2 \%$ lives in poverty and $16.4 \%$ in extreme poverty (CONEVAL, 2015 in ANUIES 2018).

The UVI is constituted as a distinct administrative unit of the larger state public university (Universidad Veracruzana), with an independent curricular model and administrative and teaching staff. UVI's first cohort started in 2005 and it was the largest so far, with 336 students entering university that year. Subsequent cohorts have been smaller - as there is no longer the pent-up demand that influenced the initial intake — and the most recent cohort of 2017 had 93 students. The campus in which fieldwork was carried out for this study currently has 220 students and 153 alumni.

UVI's main objectives are to:

- Promote the development of higher education programmes that contribute to the strengthening of intercultural regions of the state of Veracruz [...]

- Educate professionals capable of responding to social demands of their original regions and of the states through transdisciplinary academic programmes with an intercultural perspective

- Foster the participation of the communities of intercultural regions in the definition of [...] the formal curriculum, guaranteeing the required attention to the needs and main issues that hinder such regions.

- Encourage the participation of the Universidad Veracruzana alumni from intercultural regions, aiming at promoting their social ties and collaboration in educational and community development projects.

- Foster the use, teaching and dissemination of the languages and cultures of the regions where actions from the UVI administrative unit are implemented. (UVI 2018) ${ }^{3}$

The main curricular programme of the UVI is the BA in Intercultural Management for Development ${ }^{4}$ which has five different orientations: communication, sustainability, languages, law and health. Students normally choose one of these orientations, but more recently in the case study campus at least, they have been opting for two in particular cases. A second BA, Law with a Focus on Judicial Pluralism, ${ }^{5}$ has also been implemented more recently in other campuses. The educational model of the UVI is based on three interconnected areas: teaching, research and community engagement. They are the core of both the UVI as an academic

\footnotetext{
${ }^{3}$ All translations from Spanish are the authors.

${ }^{4}$ Licenciatura en Gestión Intercultural para el Desarrollo.

${ }^{5}$ Licenciatura en Derecho con enfoque de Pluralismo Jurídico.
} 
institution and the curricular programmes, since both students and staff engage in all three of them through interconnected processes.

Engagement with the community in UVI has distinctive characteristics. It is mainly carried out by students' intervention projects, lecturers' own professional activities - research that gives support to the community in specific areas such as health, language workshops etc. - and through the Regional Intercultural Advisory Councils, ${ }^{6}$ where representatives of the regional communities are consulted, give their opinion and account for UVI projects at campus and state levels. The relationship between the UVI regional campuses and the Councils aims to foster trust and reciprocal ties in order to develop projects that respond to specific problematic issues. These councils together with UVI lecturers and community representatives define areas of incidence that guide the engagement work the UVI does, as one of the UVI senior managers explained:

In the North zone, in the Huasteca, the emphasis has been placed on research around water because of the councils. The zone representatives have promoted this [...], and it is being worked on by the teaching staff and by the students in research and engagement. [...] In the South campus, called Las Selvas, because of the council and communities' representatives, the topic of buen vivir ${ }^{7}$ and food production in community fields or backyards has been put on the table. There is a particular interest about what it is that is being consumed in the communities around the campus (UVI senior manager, male)

Community engagement is one of the most highlighted traits across the narratives of the people interviewed, and as the research coordinator stated "it is not only that the university goes to the community, but that the community is part of the university" (UVI senior manager, female). Such positioning aims to promote (a) the acknowledgement of the characteristics and needs of the community as the starting point of the teaching, research and intervention/engagement processes, (b) a recognition and revalorisation of traditional knowledge and language and (c) an intercultural standing that recognises diverse views, experiences and knowledge, which starts from a position that makes valid all these different forms and aims for a constructive dialogue. This positioning is highlighted especially in the critical position that students and lecturers take regarding communities and power dynamics, as one of them stated:

Now I am realizing that I did not go to, perhaps to orient, but I did not go to teach, I went to learn from them. That particular man [from the community] would talk to us, give us his own lectures, and we started with them to work on the management of natural resources. (UVI lecturer and alumni, male)

As part of this community engagement, the UVI also provides particular services to the community, like the health brigade that attends the people of the nearby communities on the campus, the coordination of donations that are given to the regions or support in particular projects. An example of this last aspect is that the teaching staff and students were asked to act as interpreters and mediators between public upper secondary teachers, who spoke Spanish, and the families that were part of the accountability committee, which spoke the local

\footnotetext{
${ }^{6}$ Consejos Consultivos Interculturales Regionales.

${ }^{7}$ Literally "good living", a philosophy of life of harmonious coexistence originating amongst Andean indigenous groups (Brown and McCowan 2018).
} 
indigenous language Náhuatl, dealing not only with the language translation but also with the different cultural dynamics.

A second common topic relates to the relationships of care that are fostered between the teaching and managerial staff and the students. The dean explained, for example, how the lecturers support the students when they have personal problematic situations or to visit cities or other communities; they also have hosted them in their homes and provided economic resources: "The relationship between student and teacher is very strong, and there is a need for really committed teachers, that act in solidarity and kindness" (UVI dean, female). There are continuous narratives about the close ties between the actors, which disrupts previous educational experiences, as one of the alumni narrated:

My dad passed away, and I was about to drop out, it was very difficult for me, then, ah, I realized the human quality in the teachers, [...] that commitment and closeness of the teachers, at least in my case, it was what kept me going and I was able to finish properly and in time, because of the support I had from my tutor. I do not think you see those things in any university, that they are so involved. (UVI alumni, female)

\section{Contributions to the SDGs}

Given the general aims of the UVI, the profile of its main BA programme centred on development, the strong ties to the local communities and its location in marginalised areas with little access to other options of higher education, the UVI appears to be an important case to explore in relation to the SDGs. It is necessary to emphasise from the outset that neither UVI nor the IUs, as a whole, draw on the SDGs explicitly for their justification and ongoing functioning. Nevertheless, the broader UN development agenda stretching back to the Millennium Development Goals (MDGs) is evident in the rationale for the initial creation of the intercultural universities in general. Such evidence can be found in the rhetorical elements present in their founding documents (Casillas Muñoz and Santini Villar 2009) regarding development, modernisation and the inclusion of marginalised actors and are still in use to justify its need in the country. There is also a clear orientation towards teaching and researching related to the value and protection of the natural environment and its responsible use, as is the case in the SDGs.

In the UVI project, in particular, there is also a connection with the SDG framework in terms of expanding the type of population that attends higher education, since it includes indigenous, low-income and female students. It is important to state as well as through incorporating these traditionally excluded populations UVI also contributes to the broader Universidad Veracruzana targets of equity, inclusion and sustainability. This contribution helps UVI to survive as an educational project in the UV and gives it some power of negotiation in the larger university in terms of budget and academic autonomy.

This use of the SDGs and the need for "development" is thought to be a predominantly top-down narrative, in the discourses of politicians and senior management, and is not explicit in the UVI's practices. Nevertheless, the UVI, as one of its founders mentions, works directly with problematic social issues that can be related to 
development, and not indirectly or theoretically, as the conventional university is perceived to do:

The conventional university is working with abstractions, with subjective scenarios and the intercultural university works more with empirical realities that are very concrete, with hunger, they see directly what hunger means, it is not a concept, they know it, they live it and they have it there next to them (researcher 2, male)

In the narratives of the actors interviewed, some of the specific goals are highlighted. The most evident one relates to SDG4 (on education itself) and, particularly, to the possibility of accessing higher education ("By 2030, ensure equal access for all women and men to affordable and quality technical, vocational and tertiary education, including university" [UN 2015]). The students that attend UVI are mostly indigenous students from low-income backgrounds who live in rural areas with high levels of marginalisation. In many cases, they would not be able to go to university not only due to economic reasons but also because they might not meet the academic criteria to enter university. The UVI has pushed to open alternative paths of access for these students, including changing the entrance exam from a selection mechanism to a diagnostic one and basing the students' acceptance on an interview and the backing of their local communities, as the UVI dean states:

We have achieved some things, we have managed to have a differentiated entrance exam. Because they used to apply this via the same entrance exam [...] and our students always came last, and then they presented the statistics [...] and would tell the university "you have a problem, you have people that should not be at university, look at these results". And they were our students. And there I told the UV dean that that was exclusion, discrimination and that we were committing a cognitive injustice by applying that exam. And hence we have our own exam, our own process. There is an exam and an interview, but the interview can be in the language of the student if that is what $\mathrm{s} / \mathrm{he}$ chooses [...] The exam is a diagnostic exam, and we give value to the young people's expectations of wanting to work with their communities and their own community experiences. We have young craftsmen, healers, midwives, apprentices; that for us is very important, because they already have a role in their community, what we are going to do is professionalize them, so they are actors that are able to contribute more to their community. (UVI dean, female)

UVI can be seen in this way to be addressing SDG4 not only by expanding the places available and ensuring greater geographical diversity of location of institutions but also by responding to the more subtle factors that prevent accessibility (McCowan 2016b), by acknowledging both the poor quality of previous schooling of the prospective students and the value of their broader life experience. As seen above, UVI has also engaged in a continuous discussion of what an appropriate and pertinent education means, a constitutive element of quality of education whose definition carries within it important tensions and challenges, as will be explored in the next section.

In addition to the relationship with SDG4, there are contributions to a number of the other goals, including the improvement and care of the natural environment (water, energy and climate action) and health, through the specific BA orientations, the projects that are carried out and the way the UVI regional campuses are built and organised. SDG2 ("End hunger, achieve food security and improve nutrition and promote sustainable agriculture" [UN 2015]) 
can also be related to the UVI's activities mainly in connection to practices of food sovereignty. These take particular configurations given the UVI's position regarding the exploration, recognition, use and value of the communities' "traditional" notions of agricultural and animal management, and of the understanding and improvement of health. One of the alumni gave evidence on this matter:

In 2009, 2010 when the economy fell in the communities [...] I started seeing that there are sustainable alternatives to promote agriculture, to have options for the management of natural resources, that helped me to choose sustainability as my BA orientation. I started to guide my family's practices, with my dad, who [...] said "you see, you are learning something, you are learning new things", (but) I told him "there are not new things, in reality we stopped doing them, because they were things that were done before". And that was when he restarted with the previous practices, and those started to give agricultural results, in the growth of organic corn and beans [...] It was then when I started to generate my own expectations, identify my own point of view, because of the community, and from there, as a student, I started an engagement group (with the community) (UVI lecturer and alumnus, male).

UVI's practices also relate to the goal of gender equality. In connection to access to higher education, UVI students and alumni are mostly women- $68 \%$ of the currently enrolled students - and the interview narratives state how the UVI has significantly opened spaces for women who tend not to move away from their communities to study due to family expectations and economic constraints. Students and alumni also speak of a change in perceptions of gender - as shown in the statement below - and spaces for discussion have been progressively developed in this regard. Staff also speak of how it is a theme that is explicitly worked within UVI. However, less concrete examples of specific projects to address gender equality with the communities were given in comparison with the previously mentioned areas.

So I believe that to a greater or lesser extent, depending also on each context, yes UVI has had an impact on the community.... Many of the youngsters who are studying were part of the family workforce.... They used to help in the fields, sowing seeds, in the kitchen, for example, the girls are now going to study, they are not staying there. Or for example, I realise that maybe women's empowerment is not the principal objective of UVI, questions of gender, but it does happen. Or questions of sexual diversity, also many of the people who were there, they become confident enough to express themselves (UVI alumni, female)

In relation to "peace, justice and strong institutions" (SDG16), an area that is seen as particularly challenging in Mexico, the main contribution of UVI is through promoting social justice for the indigenous peoples who have endured centuries of oppression. Justice is promoted both through providing access to opportunities in the mainstream society in the education system (the redistribution element) and in enabling a space for distinctive indigenous culture and knowledge traditions (the recognition element) (Oyarzun Morel et al. 2017). An aspect relating to peace and conflict expressed by the researchers interviewed is that of the intercultural ethos of the UVI, and the opportunities for the meeting of multiple cultural and religious identities-e.g. Nahuas, Popolucas, Mestizos, Protestants, Catholics, Jehovah's 
Witnesses - which converge in the regional campus, having particular power dynamics and historical relationships that need to be considered.

Finally, the UVI's activities can also be considered in relation to the goal of "decent work and economic growth". The UVI is mostly identified in the region through the work its alumni carry out in their communities. Most of them stay in their home regions; some of them continuing with projects started as students. Two of the interviewed students spoke of this type of work as valuable for them and reflected on their intention of "becoming partners with the communities" (UVI students, females, 21 August 2017) through the development of financed projects. Although the BA encourages self-employment, most of the alumni opt for finding jobs as employees. However, job possibilities are limited in the communities and most of the positions are relatively unstable. The exit profile of the BA is also relatively new and not well known, which sometimes hinders the UVI alumni's placements. Actors also identify that a positive characteristic of the profile is its interdisciplinarity, which allows them to adapt to different areas and positions. In relation to economic growth, it is important to highlight as well that there seems to be some development in the local economy of the communities close to the regional campus, due to the migration of students to the region, particularly in terms of housing and food services.

\section{Challenges and tensions}

Besides the recognition of UVI's work in the previously mentioned areas, practically all actors interviewed put forward a critical position in relation to the international and national discourses "from the top" on development. This position was not, however, homogenous and revealed important tensions that the actors of the UVI navigate. Questions are posed for the general SDG framework concerning how to conceptualise higher education in relation to the function or role of universities, of what is and should be a graduate of universities interested in sustainable development and of the notion of development itself.

The first addresses the relationship between the students' and alumni's identities, their employment prospects and plans and the community engagement the UVI fosters. As has been mentioned, there is a recognition and encouragement of understanding UVI students not only as young people but also as indigenous students and/or as part of specific communities. The three interconnected areas of teaching, research and community engagement support a recognition of this identity and the development of a critical political position that emphasises the value of the specific community and ethnic identities, in opposition in many cases to the broader national and international narratives of modernisation and development that historically have excluded the same students' communities.

Students are therefore encouraged and sometimes expected to take an "activist" or "emancipatory" position in their communities after they graduate. In this perspective, the options of staying in their regions, becoming self-employed, working for NGOs and engaging in a way that favours their local community are presented to students during and after their BA. The UVI as an academic unit tends to foster therefore agreements and ties to these types of actors, and not with large companies, such as the national oil company or agricultural enterprises. One of the UVI senior managers recognised in this regard that there is a "ethical and political intentionality; we recognize that there is an adverse, unjust, unequal context, and we aspire to intercede in that forced relationship so things in the communities' lives can improve" (UVI senior manager, female). 
At times, however, this orientation confronts students' and especially their families' notions of social mobility and success, and also the real possibilities of employment presented in this context. Staff and alumni recognise this tension and the difference in opinion and political positioning on the matter. Amongst the leadership at UVI, there is recognition of the need to promote employment for the students and their communities:

We have seen that the students who are to graduate do have an imaginary construct about employment; of being employed in the municipality, in the CDI [National Indigenous People Development Commission] in the health system. There is a need for employment, which is completely understandable [...] not only for the fact that the graduates want a job, but because there is a construct in the community that has lead the students into that dilemma. The students tell us in their last semester that when they'll get to their communities, the people do not want them to do the same things, right? They do not want them to work in the fields, because they see it as a step back [...] (UVI campus manager, male)

However, another lecturer argues for the need to keep the critical and ethical positioning that might be hindered if notions and processes of production are highlighted:

There are also teachers who have an orientation towards more mainstream notions of development "to produce, we have to teach the young to produce" [...] and if you ask me, I would say "not at all"; the students might need it, but they also need to adopt a historical position regarding colonial debts and wounds. It is important that the student is employable, but you cannot go all the way and discard any other type of more critical and ethical positioning for a vision of "the only thing needed is that you are employable". (UVI lecturer, male)

Some of the alumni recognise this tension as well, and although stating the importance given to the perspective fostered by UVI, they also identify the need for elements in the curriculum linked more to technical aspects, administration and budgeting.

In addition to the question of employment, UVI also presents challenges to the notion of identity, and particularly to the changes of identity and accrual of status that comes with formal education:

In my house my dad says "well, why do you go to that university? I made a mistake in letting you go there", because he says "I thought you would come back and you would not tend to the fields anymore, you would not do this anymore; why do you talk to the people that speak Náhuatl? You have to talk to people with studies". So that is the debate with the community, because once you come to university people think that you are going to - how do you say? - go up socially or something like that, and that is a debate, because to come to uni is to be socially above. (student 1)

Another student added:

Maybe when we had just started uni, it is like one wants to move up, but then you realise it's not like that, things are not like that. One changes that way of thinking, and here we 
learn to be the same as the rest of the people, not above, and not below. We do not lose what we have learned, but we have to mediate, we have to respect the other (UVI student, female)

A common critique of the SDGs from all interviewed actors is the lack of recognition of cultural and local identities, and in the case of the UVI's communities, of the indigenous demands for recognition and autonomy. In contrast, the actors present a discourse of interculturality as a central characteristic of development. There is a strong component in all of the actors' narratives of the importance of the recognition and value of their culture, reflecting a revalorisation of their ethnic and community identities. This recognition is linked to the revitalisation of indigenous languages in university and a deeper understanding of their local context, as one alumna shared:

I participated in my community's celebrations, but I had not realized how important they were for the construction of identity. I started to reflect on that, on those ideas of who I was. I always say that for me, there is a before and after UVI. There were many things that I did not see, but that they were there, and through my studies in UVI they became visible, I even reinforced my sense of belonging to a group. I did not recognize myself as Afro-Mexican, I did not know what were the origins (of the community) [..] many things I did not question about my sense of belonging and identity, they were awoken by my process in UVI (UVI alumni, female)

There are however tensions around what interculturality means not only as a notion but also as a process and set of practices to be developed and encouraged in university. These tensions are more explicitly recognised in the staff and researchers' narratives than in the students and alumni. There are broadly two main perspectives, one that seems to be more politically positioned in favour of responding to the historic debt towards indigenous populations and emphasises addressing inequalities, and the other that relates more to a multicultural "European" view of interculturality, which highlights learning from diversity and creating more harmonious relationships.

Another important feature of the UVI experience is a questioning of the notion of development - both the more blatant forms of economistic modernisation and the more subtle forms associated with sustainable development - and amongst some actors at least, counterhegemonic views. The notion of development and the practices developed in this university seem to be influenced not only by the position the actors take regarding the tensions discussed above around employment and interculturality but also by broader questions of what constitutes a "good life", and of who gets to decide what development and poverty is, as a student expressed:

I could analyse the first one [SDG], "no poverty". In that one I do not know what is for them "poverty", because I've read that for the health or social development secretariat they say that poor is a person who does not have a stove, sewer, fridge or who has a dirt floor. They are poor. But in here, it is different, maybe they do not have cemented floors, but they have the fields, they have spaces for planting and harvesting, from there they gain their food, so the person might not be poor [...] and that makes me think, where do we look at poverty from and decide what is development for one and development for the other? (UVI student, female, 21 August 2017) 
Overall, there seems to be a joint critique in the narratives collected in this project of assistentialist views of development that are used in the rhetoric, policies and practices of international and national institutions - like in some of the justifications for Intercultural Universities and the need to provide education for indigenous, rural and excluded populations. Even with the tensions expressed above, most UVI actors tend to promote what can be considered more grassroots, autonomous and "bottom-up" logics of development.

(The students say that their parents) get mad because we start to speak Náhuatl, they say “if I have taught you to speak Spanish it's so you don't suffer in society, so you can get out of poverty [...] so you have another identity. If you learn Náhuatl and start to practice it, it's like you are going back to where you were before." And I tell them that is not the case, that we are choosing something that they are selling to us, that is not our own. We offer them modules that strengthen and transform our own lives [...] (The families) say that what the students are studying in UVI does not take them out of poverty; but if they realise that poverty, for them, is to speak Náhuatl [...] to keep practicing our roots, then poverty is another thing, it has another meaning. So, there are different social and community points of view, as there are in academic life (UVI lecturer and alumnus, male)

It is important to state, however, that this critical positioning towards development and its connection to modernity does not seem to appear in the narratives of all members of the community. The people UVI students work directly with (in what are called engagement groups) recognise the commitment of the students and alumni towards them, the work they carry out together and the learning that this engagement has developed. Yet other community actors, such as local authorities, do not explicitly recognise the profile of the UVI students and view the university more in terms of the opportunity it provides for the local communities, without much differentiation from other higher education options present in the region.

\section{Discussion}

Cases like the Intercultural University of Veracruz illuminate important aspects of the relationship between higher education and the new international development settlement, concretised in the Sustainable Development Goals. On the one hand, UVI shows enhanced effectiveness in addressing some of the most intractable development challenges, particularly in reaching marginalised populations, with a nimbleness and responsiveness lacking in many mainstream universities. On the other hand, it presents a challenge to that framework, embodying alternative approaches to development and highlighting silences in the global goals.

As shown in the earlier sections, UVI contributes to the access dimension of SDG4 through enabling participation of groups which - through their remote geographical location or gendered social responsibilities - struggle to attend mainstream institutions. The scenario is changing in Mexico, and the development of the subsystem of public technical institutions over the last 25 years has increased the possibilities for those living in rural areas. The intercultural universities are no longer the only option for indigenous Mexicans, therefore, but they do contribute to the expansion of access, particularly for female students. 
More significant, however, is that UVI represents a different model of institution with some very distinctive features. There is a high level of integration between teaching, research and community engagement, with strong synergies between the three. Community-based research is an important part of the learning process for students in undergraduate courses, and lecturers are strongly engaged in community work, which they draw on in their teaching and research. Despite lip service to community engagement in most institutions, the walls are still high between many universities (in particular elite universities) and their surrounding communities (in particular low-income communities). When achieved, a strong, meaningful and horizontal relationship between higher education institutions and local communities can prove transformative for both.

In addition to offering enhanced work prospects to individual students, UVI also shows a strong orientation of its work towards the public good, through the knock-on benefits of locally based professionals, and directly through its community-based work - thereby addressing calls by many commentators for more publicly oriented universities (Locatelli 2019; Marginson 2011; Singh 2012). The university also has a critical role in the local community as an "anchor institution" (Birch et al. 2013), in promoting economic opportunity as well as cultural activity and political empowerment, showing the importance of place-based higher education. In turn, there is a strong involvement of community members within the institution, allowing for a closer alignment of priorities.

Nevertheless, it is clear from the findings presented above that this intercultural university does not obediently serve the mainstream developmental model, but lays down a number of challenges to it. One of the most striking aspects of the data emerging from student interviews is the process of transformation in relation to indigenous culture. Many students had started to value their own knowledge of Náhuatl or other indigenous languages for the first time and to feel comfort and pride in speaking it within an educational setting. Culture and language are for the most part lacking in the SDG framework, as is an intrinsic valuing of community, thus ignoring the source of value for a substantial proportion of humanity.

The UVI experience also poses challenges to mainstream conceptions of education and development. As outlined in the previous section, the students describe powerful experiences of challenging preconceptions about the necessary separation of the individual from the community and culture through formal education and show that it is possible for a graduate to live in an indigenous community, speak an indigenous language and work in the fields, but nevertheless be putting to good use the knowledge gained from university. Notions of development as modernisation and economic growth have also been challenged, opening spaces for alternative conceptions such as buen vivir (Brown and McCowan 2018; Villalba 2013) and the possibility of holistic approaches to knowledge. To provide an example, UVI was the origin of the alternative currency called Túmin, which has gained some prominence in Mexico as a mechanism for reviving local communities through a solidarity-based economy. Nevertheless, there are many different visions and political positionings within the intercultural universities, and not all of the university community shares these counterhegemonic views.

This case, therefore, illustrates some of the characteristics of the "post-development" university, as outlined in McCowan (2019). In relation to the dialogue of knowledges aspect, UVI provides an unusually rich meeting place between mainstream Mexican/Western cultures and indigenous cultures, through the multilingual environment, the integration of learning oncampus with learning in the community, the combination of knowledge traditions and respect for and recognition of different ethnicities. As regards deinstitutionalisation, the university 
maintains its presence in the mainstream system and offers nationally recognised degrees, but does experiment with new forms of admissions, pedagogy, curriculum and staffing.

There are, as would be expected, difficulties encountered by the intercultural university sector in Mexico. UVI has enjoyed cushioning from political manoeuvring through its nesting within the autonomous Universidad Veracruzana, while most other intercultural institutions have been subject to the dynamics of state governments. Recruiting appropriate staff members has proved difficult, in terms of engaging well-qualified research-active academics who are also committed to the intercultural vision and are willing to work in relatively remote locations. Furthermore, the numbers studying in these institutions are small, so they are constantly battling to justify themselves as an efficient allocation of resources.

Many of the benefits provided by UVI — both in line with the SDGs and looking beyond them-would have been unlikely through mainstream higher education institutions. Contemporary higher education systems are characterised by a small number of elite researchintensive universities, surrounded by a large number of demand-absorbing institutions, in many cases private and for profit. For different reasons, neither of these types of institution is well placed to generate public good benefits for local populations: in the case of the former on account of the emphasis on international rankings that leads them away from local relevance and inclusive admissions, and in the latter through the profitability measures which make research and community engagement a rarity (McCowan 2019).

For governments and supranational agencies, therefore, affordability should be just one of a range of considerations in relation to higher education and the SDGs. It is essential also to consider the nature of the institution and its possibilities for addressing the diverse goals. In doing so, attention to local innovations is vital for enriching our imagination and understanding of the possibilities of higher education and in finding solutions that will take root and blossom in real contexts around the world.

Acknowledgements This study was supported by a grant from the UCL Institute of Education seed fund. We would like to thank Gunther Dietz for his support, and UVI and all the research participants for their collaboration and hospitality during the research.

Open Access This article is licensed under a Creative Commons Attribution 4.0 International License, which permits use, sharing, adaptation, distribution and reproduction in any medium or format, as long as you give appropriate credit to the original author(s) and the source, provide a link to the Creative Commons licence, and indicate if changes were made. The images or other third party material in this article are included in the article's Creative Commons licence, unless indicated otherwise in a credit line to the material. If material is not included in the article's Creative Commons licence and your intended use is not permitted by statutory regulation or exceeds the permitted use, you will need to obtain permission directly from the copyright holder. To view a copy of this licence, visit http://creativecommons.org/licenses/by/4.0/.

\section{References}

Alcántara Santuario, A., \& Navarrete Cazales, Z. (2014). Inclusión, equidad y cohesión social en las políticas de educación superior en México. Revista Mexicana de Investigación Educativa, 19, 213-239.

ANUIES. (2018). Visión y acción 2030. Propuesta de la ANUIES para renovar la educación superior en México. México: ANUIES.

Araujo Echevarría, H. (2013). Universidad Intercultural y comunidad anfitriona. Vínculos, relaciones y perspectivas en torno a la Universidad Veracruzana Intercultural sede Huasteca. México: Universidad Veracruzana, Xalapa (MA dissertation). 
Ávila Pardo, A., \& Cortés Mateos, L. (2008). Configuración de actores y discursos híbridos en la creación de la Universidad Veracruzana Intercultural. TRACE., 53, 64-82.

Ávila Romero, A., \& Ávila Romero, L. (2014). El asalto a la interculturalidad: las universidades interculturales de México. Argumentos., 27, 37-54.

Bermúdez Urbina, F., González Apodaca, E. (2016). ¿Es posible caracterizar al (los) sujeto (s) de la ESI? La investigación sobre Trayectorias académicas en Universidades Interculturales y otras instituciones de Educación Superior Intercultural en México., in: 14. Diversidad Social y Cultural: Transformaciones y Continuidades. Presented at the 5to Congreso Nacional de Ciencias Sociales, CUCSH - UDG, Guadalajara. 226-251.

Bertely Busquets, M. (2011). Educación superior intercultural en México. Perfiles educativos, 33, 66-77.

Birch, E., Perry, D. C., \& Taylor Jr., H. L. (2013). Universities as anchor institutions. Journal of Higher Education Outreach and Engagement., 17(3), 7-15.

Brown, E., \& McCowan, T. (2018). Buen vivir: Reimagining education and shifting paradigms (forum). Compare, 48(2), 317-323.

Casillas Muñoz, M. d. L., \& Santini Villar, L. (2009). Universidad Intercultural: modelo educativo. CGEIB-SEP: México D.F.

CDI. Comisión Nacional para el Desarrollo de los Pueblos Indígenas. (2015a). Sistema de indicadores sobre la población indígena de México. México City: CDI.

CDI. Comisión Nacional para el Desarrollo de los Pueblos Indígenas. (2015b). Atlas de los pueblos indígenas de México. México City: CDI http://atlas.cdi.gob.mx/?page_id=7254. Accessed 15 Oct 2019.

CONAPO. Consejo Nacional de Población. (2018). Proyecciones de la Población 2010-2050. Mexico City: CONAPO.

Didou-Aupetit, S. (2013). Cooperación internacional y educación superior indígena en América Latina: constitución de un campo de acción. Revista iberoamericana de educación superior., 4, 83-99.

Dietz, G. (2008). La experiencia de la Universidad Veracruzana Intercultural. In Mato, D. (coord.), Diversidad Cultural e Interculturalidad en Educación Superior. Experiencias en América Latina. Bogotá: IESALCUNESCO. 359-370.

Dietz, G. (2009). Intercultural universities in Mexico: Empowering indigenous peoples or mainstreaming multiculturalism? Intercultural Education, 20(1), 1-4.

Dietz, G. (2012). Diversity regimes beyond multiculturalism? A reflexive ethnography of intercultural higher education in Veracruz, Mexico. Latin American and Caribbean Ethnic Studies, 7, 173-200.

Dietz, G. \& Mateos Cortés, L. (2010). Saberes, haceres y poderes en la UVI: hacia una investigación intercultural e interactoral. La palabra y el hombre. 12. n.p.

DOF. Diario Oficial de la Federación. (2019) DECRETO por el que se reforman, adicionan y derogan diversas disposiciones de los artículos 3o., 31 y 73 de la Constitución Política de los Estados Unidos Mexicanos, en materia educativa. México: Congreso de la Unión.

Escobar, A. (1995). Encountering development: The making and unmaking of the third world. Princeton University Press.

Esteban, M., Bastiani, J., \& Vila, I. (2009). El impacto de la cultura en el autoconcepto. Un estudio con mestizos de distintos entornos educativos de Chiapas. Cultura y Educación, 21(3), 361-370.

Fábregas Puig, A. (2009). Cuatro años de educación superior intercultural en Chiapas. In Mato, D. (coord.) Instituciones Interculturales de Educación Superior En América Latina. Procesos de Construcción, Logros, Innovaciones y Desafios. Carácas: UNESCO - IESALC. 251-278.

García, S., \& Bastida Muñoz, M. (2012). Un paradigma educativo intercultural para impulsar la paz y el desarrollo local de las comunidades originarias: El programa de Desarrollo Sustentable de la Universidad Intercultural del Estado de México (UIEM). Ra Ximhai, 8(3), 17-31.

Gómez Navarro, D. (2013). La construcción del habitus y ethos profesional de las/los estudiantes y egresados de la Universidad Veracruzana Intercultural (UVI), sede Selvas. In Jiménez Naranjo, Y.; Alatorre Frenk, G. (coord.). Construyendo Interculturalidad En Veracruz: Miradas, Experiencias y Retos. Xalapa: Universidad Veracruzana. 105-124.

Gómez Navarro, D. (2014). Profesionistas emergentes: gestores y gestoras interculturales para el desarrollo en el sur de Veracruz. In Pérez Ruiz, M., Ruiz Lagier, V. \& Velasco Cruz, S. (coord.). Interculturalidad (Es)Jóvenes Indígenas: Educación y Migración. Ciudad de México: UPN. 137-168.

González Ortíz, F. (2007). Cultura y desarrollo desde la interculturalidad: breve recuento de la primera Universidad Intercultural de México. Ra Ximhai, 3(2), 243-272.

Guzmán Gamés, F. (2014). Capitales tecnológicos y trayectorias escolares en la Universidad Veracruzana Intercultural sede Huasteca. Xalapa: Universidad Veracruzana (MA dissertation).

INEE. Instituto Nacional para la Evaluación de la Educación. (2019). Panorama Educativo de México 2018. Indicadores del Sistema Educativo Nacional. Educación básica y media superior. Ciudad de México: INEE. 
INEGI. Instituto Nacional de Estadística y Geografia. (2016). Encuesta Nacional de Ingreso y Gasto de los Hogares: Nueva serie. Retrieved from INEGI website: https://www.inegi.org.mx/programas/enigh/nc/2016/. Accessed 15 Oct 2019.

Lebrato, M. (2016). Diversidad epistemológica y praxis indígena en la educación superior intercultural en México: Un caso de estudio en el Instituto Superior Intercultural Ayuuk. Revista Mexicana de Investigación Educativa, 21(70), 785-807.

Lehmann, D. (2015). Convergencias y divergencias en la educación superior intercultural en México. Revista mexicana de ciencias políticas y sociales. 223 (enero-abril), 133-170.

Llanes Ortíz, G. (2009). Indigenous Universities and the construction of interculturality: the case of the Peasant and Indigenous University Network in Yucatan, Mexico. Brighton: University of Sussex (PhD thesis).

Locatelli, R. (2019). Reframing education as a public and Common Good. Enhancing democratic governance. London: Palgrave Macmillan.

Marginson, S. (2011). Higher education and public good. Higher Education Quarterly, 65(4), 411-433.

Mateos Cortés, L. (2008). Configuración de redes migratorias. En torno al discurso de la interculturalidad. Sociedad y Discurso. 13, 1-15.

Mateos Cortés, L. (2015). La formación de gestores interculturales: jóvenes profesionistas egresados de la Universidad Veracruzana Intercultural. Revista Interamericana de Educación de Adultos, 37(2), 65-81.

Mateos Cortés, L \& Dietz, G. (2014). Los estudios interculturales en la Universidad Veracruzana: hacia un primer balance. CPU-e, Revista de Investigación Educativa. Special Issue. 57-79.

Mateos Cortés, L., \& Dietz, G. (2016). Universidades interculturales en México: balance crítico de la primera década. Revista Mexicana de Investigación Educativa, 21(70), 683-690.

Mateos Cortés, L., Dietz, G., \& Mendoza Zuany, R. (2016). ¿Saberes-haceres interculturales? Experiencias profesionales y comunitarias de egresados de la educación superior intercultural veracruzana. Revista Mexicana de Investigación Educativa, 21(70), 809-835.

McCowan, T. (2016a). Universities and the post-2015 development agenda: An analytical framework. Higher Education, 72(4), 505-525.

McCowan, T. (2016b). Three dimensions of equity of access in higher education. Compare, 46(4), 645-665.

McCowan, T. (2019). Higher education for and beyond the sustainable development goals. London: Palgrave Macmillan.

Mendoza Zuany, R. (2009). Gestión intercultural en el ámbito de los derechos humanos en México: retos de la Universidad Veracruzana Intercultural. Cuadernos Interculturales, 7(13), 125-140.

Mendoza-Rojas, J. (2015). Ampliación de la oferta de educación superior en México y creación de instituciones públicas en el periodo 2001-2012. Revista Iberoamericana de Educación Superior, 6(16), 3-32.

Mendoza-Rojas, J. (2018). Subsistemas de Educación Superior. Estadística básica 2006-2017. Ciudad de México: DGEI-UNAM.

Merriam, S. (1998). Qualitative research and case study applications in education. San Francisco: Jossey-Bass.

Meseguer Galván, S. (2013) Perspectiva intercultural de los imaginarios instituidos e instituyentes de los universitarios rurales. Devenir. Mayo-agosto (Cuarta época). 141-159.

Morales Silva, C. (2012). Hábitos culturales y postproducción en jóvenes estudiantes de la UVI-Huasteca. LiminaR., 10(1), 46-57.

Moreno Arriba, J. (2016). Diálogo de saberes y colaboración social intercultural: El ejemplo de la universidad veracruzana intercultural sede selvas. Discurso y prácticas de los actores protagonistas. Sociedad y Discurso, $28,254-281$.

OECD. (2019). Higher education in Mexico: Labour market relevance and outcomes. Paris: OECD Publishing, Paris.

Olivera Rodríguez, I. (2017). Las potencialidades del proyecto educativo de la Universidad Veracruzana Intercultural: una crítica al desarrollo desde la noción del Buen vivir. Revista de la Educación Superior., 46(181), 19-35.

Oviedo Mendiola, M. (2014). "De la primaria a la universidad: trayectorias de formación de jóvenes indígenas en universidades de México", en Didou Aupetit, S. (coord.), Los programas de educación superior indígena en América Latina y en México: componentes tradicionales y emergentes, México/Caracas: CONALMEX/ Unesco-IESALC. 171-188.

Oyarzun Morel, J., Perales Franco, C., \& McCowan, T. (2017). Indigenous higher education in Mexico and Brazil: Between redistribution and recognition. Compare, 47(6), 852-871.

Patton, M. (1990). Qualitative evaluation and research methods. Beverly Hills: Sage.

Prakash, M. S., \& Esteva, G. (2008). Escaping education: Living as learning in grassroots cultures (2nd edition). New York: Peter Lang Publishing.

Rahnema, M., \& Bawtree, V. (Eds.). (1997). The post-development reader. London: Zed.

Re, A. (2013). Universidades Interculturales en México. Reflexiones sobre Identidades a partir de un trabajo de campo en Espinal, Veracruz. Barcelona: Universitat de Barcelona, Universitá degli studi di Roma "La Sapienza"(PhD thesis). 
Rojas Cortés, A. (2016). Educación superior intercultural y comunitaria. Dimensiones actorales e institucionales en México y Oaxaca. In: 14. Diversidad Social y Cultural: Transformaciones y Continuidades. Presented at the 5to Congreso Nacional de Ciencias Sociales, CUCSH - UDG, Guadalajara. 184-209.

Salmerón Castro, F. (2013). Avances, retos y perspectivas de la educación intercultural a nivel superior. In Hernández Loeza, S.; Ramírez Duque, M.; Manjarrez Martínez, Y. \& Flores Rosas, A. (coord.). Educación Intercultural a nivel superior: reflexiones desde diversas realidades latinoamericanas. México: UIEP/ UCIRED /UPEL. 343-349.

Sandoval Forero, E., \& Guerra García, E. (2007). La interculturalidad en la educación superior en México. Ra Ximahi, 2(3), 273-288.

Sartorello, S. (2009). Una perspectiva crítica sobre interculturalidad y educación intercultural bilingüe: El caso de la Unión de Maestros de la Nueva Educación para México (UNEM) y educadores independientes en Chiapas. Revista latinoamericana de educación inclusiva, 3(2), 77-90.

Sartorello, S. (2016). Convivencia y conflicto intercultural: jóvenes universitarios indígenas y mestizos en la Universidad Intercultural de Chiapas. Revista Mexicana de Investigación Educativa, 21(70), 719-757.

Schmelkes, S. (2008). Creación y desarrollo inicial de las universidades interculturales en México: problemas, oportunidades, retos. In Mato, D. (coord.) Diversidad Cultural e Interculturalidad en Educación Superior: Experiencias en América Latina. Bogotá: IESALC-UNESCO.

Schmelkes, S. (2009). Intercultural universities in Mexico: Progress and difficulties. Intercultural Education, 20(1), 5-17.

Silva Laya, M. (2019). Tres iniciativas de equidad educativa universitaria en la Ciudad de México. Revista Mexicana de Investigación Educativa, 24(80), 43-68.

Singh, M. (2012) Re-inserting the 'public good' into higher education transformation in Leibowitz. In Brenda (ed), Higher Education for the public good - views from the south Trentham books Stoke on Trent UK and sun media, Stellenbosch pp 1-16.

Tapia Guerrero, L. (2016). El subsistema de universidades interculturales en México. Entre la política social y la política educativa. Revista Latinoamericana de Estudios Educativos, 46(1), 7-50.

UN. United Nations (2015). Sustainable Development Goals. New York: United Nations Department of Public Information. at: https://sustainabledevelopment.un.org. Accessed 15 Oct 2019.

UVI. Universidad Veracruzana Intercultural (2018). Misión, Visión y Objetivos - UV-Intercultural in https://www. uv.mx/uvi/mision-vision-y-objetivos/ (accessed 3.8.18).

Vavrus, F., \& Bartlett, L. (2006). Comparatively knowing: Making a case for the vertical case study. Current Issues in Comparative Education, 8(2), 95-103.

Villa, J. (2015). Evaluación de resultados de proyectos productivos implementados en el municipio de Tlaquipa, Veracruz, México. Presentation in III Coloquio de Interculturalidad. Diversidad y políticas públicas. 19-21 October, Puebla, México.

Villalba, U. (2013). Buen vivir vs development: A paradigm shift in the Andes? Third World Quarterly, 34(8), $1427-1442$.

Publisher's note Springer Nature remains neutral with regard to jurisdictional claims in published maps and institutional affiliations. 